\title{
On the Swelling of Erythrocytes in Isotonic Solution of Various Cations in Cases of Several Internal Diseases
}

\author{
By \\ Hiroshi Takahagi \\ (高哽浩) \\ (From the Medical Clinic of Prof. F. Na ka za wa, Faculty of \\ Medicine, Tohoku University, Sendai) \\ (Received for publication, July 9, 1951)
}

When a pathological mechanism occurs in a human body, many remarkable abnormal phenomena, namely symptoms come into sight and at the same time some delicate changes can be seen directly or indirectly. Taking the phenomenon of swelling of erythrocytes under a certain condition, the problem has been investigated in cases of various diseases.

With regard to the swelling of tissue and substance Loeb ${ }^{1)}$ and others ${ }^{2-7}$ ) have made fundamental investigations of the human tissue and especially the muscle, gelatine and some glue board. In our laboratory Sato, ${ }^{8)}$ Oyama and Sone, ${ }^{\text {9 }}$ Shimizu and Takahagi ${ }^{10}$ ) have made experiments on the swelling of some tissues. The research on the swelling of erythrocytes which play the greatest role in keeping the vital activity of human body and reacting quickly upon the pathological mechanism, have been done by Koeppe ${ }^{11}$ and others. ${ }^{12)-15)}$ However these studies were only basic and theoretical and no investigation has been made directly on patient's blood. To this date, the true mechanism of swelling is still unclassified. Hofmeister ${ }^{2}$ ) considered it as a nonchemical phenomenon between the swelling body and the medium: Loeb and others considered that the swelling in a body was due to a gelatinaus compound of protein and water; Schwarz, ${ }^{17}$ Spiro and Ostwald ${ }^{18)}$ and others have proved experimentally and theoretically that $\mathrm{pH}$, salts, and the other conditions cause complicated effects to the gelatine compound to induce a complicated reaction; but, whatever be the case, the swelling is merely to be considered that the volume of the swelling body increases as the result of absorbing the surrounding water in itself. Needles to say, the swelling body in an organism is protein. It is a self-evident truth that a medium including protein absorbs water into it and is influenced by quantitative and qualitative change of that protein. Oyama and Son $\epsilon^{9}$ in our laboratory proved that there is a parallel relation between the degree of the swelling of tissue 
and the colloid-osmotic pressure when the tissue protein is changed into a condition of sol, so therefore, as erythrocytes consists of a great deal of protein, it can be stated that the major cause for the swelling of erythrocyte is protein in the erythrocytes.

Nakazawa ${ }^{19}$ ) has previously reported that pratein and colloid-osmotic pressure of blood plasma show various changes in various diseases. Therefore I believe that protein in erythrocytes may disclose some changes in various grades in various diseases and that the swelling of erythrocytes under a certain condition will be able to show minute variations. As there are many complicated factors in a human body, the phenomenon of swelling may become very complicated; however, we can experiment on the swelling in vitro in constant condition very easily. It is my hope that this work will give some convenience to the diagnosis and judgment of prognosis of diseases, by undertaking the study on the swelling of erythrocytes in various diseases under the above mentioned condition.

\section{EXPERIMENTAL}

\section{Method}

As medium solution I used the isotonic chloride solutions of 4 kinds of cations: $\mathrm{Na}, \mathrm{K}, \mathrm{Ca}$ and $\mathrm{Mg}\left(0.9 \% \mathrm{NaCl}, 1.14 \% \mathrm{KCl}, 2.52 \% \mathrm{CaCl}_{2}\right.$ and $2.34 \% \mathrm{MgCl}_{2}$ ). Most of the examines were the inpatients of Prof. Nakazawa's Medical Clinic. Blood samples were taken from patient's cubital vein free from congestion prior to the patient's breakfast time, and immediately after defibrination, centrifuged in an electric centrifuge ( 3000 R.P.M.) for 30 minutes, mixed thoroughly after removing the blood serum, a layer of leucocytes and a small amount of erythrocytes.' 4 testtubes each containing $2.5 \mathrm{cc}$. of above mentioned isotonic cation solutions were prepared and to which $0.5 \mathrm{cc}$. of erythrocytes was added respectively. A homogenous suspensive fluid of erythrocytes was thereby obtained by gently mixing the solutions. The test-tubes were then allowed to stand 30 minutes in an incubator at $37^{\circ} \mathrm{C}$. The measuring of the swelling was undertaken immediately after removing the test-tubes from the incubator. In order to measure the swelling, I used a small graduated tube for precipitation which was especially made for this purpose: a glass-tube $100 \mathrm{~mm}$. long, with a true inside diameter of $5 \mathrm{~mm}$., graduation of 150 and $1.5 \mathrm{cc}$. volume.

Examination procedure was as follows: $1.5 \mathrm{cc}$. of the mixture of erythrocytes and cation solution was poured into each of the 4 tubes for precipitation, and centrifuged at 3.000 R.P.M. for 20 minutes. Then, noted the volume of swelling by reading the height of the layer of erythrocytes at the bottom of the tubes. As an aiding factor, the rest of mixture of erythrocytes and cation solutions were placed in Westergren's 
tubes for blood sedimentation rate, and read the sedimentation rate every hour for 6 hours while being kept in a box whose temperature was constantly kept at $20^{\circ} \mathrm{C}$. However, by Westergren's method, the results cannot be clearly observed because of the hemolysis. which occurs in the course of observation, therefore Westergren's method is suitable for reference purposes only. For sake of convenience, the swelling in the $\mathrm{Na}$ solution is represented by $\mathrm{Na-swelling}$ and likewise: $\mathrm{K}$-swelling represents the swelling in $\mathrm{K}$-solution. Ca-swelling represents the swelling in $\mathrm{Ca}$ solution. etc.

\section{Results}

\section{Healthy persons}

26 persons were selected for experiment- 12 males and 14 femalesfrom a group of healthy laboratory workers, laboratory assistants and nurses. These persons were examined and their swelling of erythrocytes was measured as shown in Tab. I.

The values of swelling by this method, under average conditions, were: $2.0-2.7$ on Na-swelling, $2.0-2.6$ on $\mathrm{K}$-swelling, $2.0-2.5$ on $\mathrm{Mg}$ swelling and 1.4-2.0 on Ca-swelling. Ca-swelling showed the least visual change. It was difficult to read the values of the swelling of other solution by Table observations only. Statistical examination was made as 26persons by use of various cations as indicated in Fig. 1: On comparing Na-swelling with K-swelling, no significant difference was found: the level of significance is $5 \%$, because the mean of the difference of individual values $(M)$ is +0.042 and the unbasised estimate of population variance $\left(\mathrm{U}^{2}\right)$ is 0.052 .

When comparing $\mathrm{K}$-swelling with $\mathrm{Mg}$-swelling, $\mathrm{M}=+0.173$, and $\mathrm{U}^{2}=0.045$, were obtained. In such a case the significant difference, though very small, existed and the fact was recognized that $\mathrm{Mg}$-swelling is less than $\mathrm{K}$-swelling. In the next instance, comparing $\mathrm{Mg}$-swelling with $\mathrm{G}$-swelling, $\mathrm{M}=+0.519$ and $\mathrm{U}^{2}=0.093$, were obtained and thereby showing a remarkable and a significant difference. The value of $\mathrm{Ca}$ swelling was very small compared with that of $\mathrm{Mg}$-swelling, i.e., the fact was established that Ga-swelling was the least of the 4 kinds of cations, and accordingly, the order of the value of swelling of erythrocytes in each of the cation solution was: $\mathrm{Na}=\mathrm{K}>\mathrm{Mg}>\mathrm{Ca}$.

According to the former study on the swelling of a piece of liver by Sato, ${ }^{8)}$ Oyama and Sone, ${ }^{\text {P) }}$ and Shimizu and Takahagi ${ }^{10)}$ in our laboratory, the order of the values of swelling in $\mathrm{Na}, \mathrm{K}, \mathrm{Mg}$ and $\mathrm{Ca}$, for swelling of liver tissue was found to be as follows: $\mathrm{K}>\mathrm{Na}>\mathrm{Ca}>\mathrm{Mg}$. This order has a quite different appearance as compared with that of erythrocytes, and especially it showed a remarkable difference i.e., $\mathrm{Ca}$-swelling was less than 
TABIE I

\begin{tabular}{|c|c|c|c|c|c|c|}
\hline Nr. & Age : & ader & $\mathrm{NaCl}$ & $\mathrm{KCl}$ & $\mathrm{MgCl}_{\mathbf{2}}$ & $\mathrm{CaCl}_{2}$ \\
\hline 1 & 26 , & ઠ & 2.5 & 2.5 & 2.1 & 2.0 \\
\hline 2 & 30, & ธ & 2.5 & 2.35 & 2.0 & 2.0 \\
\hline 3 & 31, & o & 2.3 & 2.3 & 2.3 & 1.8 \\
\hline 4 & 41, & tọ & 2.35 & 2.8 & 2.75 & 2.0 \\
\hline 5 & 18, & 今 & 2.9 & 2.25 & 2.15 & 1.7 \\
\hline 6 & 20, & ธิ & 2.4 & 2.35 & 2.1 & 1.05 \\
\hline 7 & 14, & $\delta$ & 2.4 & 2.3 & 2.5 & 1.2 \\
\hline 8 & 20, & $\delta$ & 2.0 & 2.05 & 2.15 & 1.7 \\
\hline 9 & 19, & ชิ & 2.4 & 2.4 & 2.3 & 1.4 \\
\hline 10 & 42 & 후 & 2.6 & 2.1 & 2.4 & 1.9 \\
\hline 11 & 32 , & 今 & 2.4 & 2,5 & 2.3 & 1.7 \\
\hline 12 & 60, & $\widehat{\delta}$ & 1.8 & 2.0 & 2.1 & 1.6 \\
\hline 13 & 22, & 우 & 2.7 & 2.4 & 2.5 & 1.9 \\
\hline 14 & 21, & 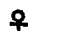 & 2.4 & 2.95 & 2.0 & 2.0 \\
\hline 15 & 21, & 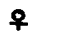 & 2.5 & 2.4 & 2.25 & 1.4 \\
\hline 16 & 20, & $q$ & 2.5 & 2.4 & 2.5 & 2.0 \\
\hline 17 & 53 , & ㅇ & 2.8 & 2.5 & 2.8 & 2.3 \\
\hline 18 & 30, & ㅇ & 2.7 & 2.0 & 2.35 & 1.7 \\
\hline 19 & 22, & 우 & 2.8 & 2.6 & 2.4 & 2.1 \\
\hline 20 & 20 & 9 & 2.5 & 2.4 & 2.15 & 1.7 \\
\hline 21 & 18, & 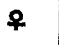 & 2.15 & 2.4 & 2.0 & 1.6 \\
\hline 22 & 19, & 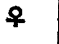 & 2.3 & 2,5 & 1.75 & 1.7 \\
\hline 23 & 19, & ? & 2.5 & 2.45 & 2.1 & 1.9 \\
\hline 24 & 27, & ㅇ & 2.6 & 2.6 & 2.6 & 2.0 \\
\hline 25 & 23, & f & 2.4 & 2.5 & 2.1 & 1.6 \\
\hline 26 & 25 , & q & 2.4 & 2.5 & 2.3 & 1.8 \\
\hline
\end{tabular}

Mg-swelling. It is recognized the fact that there is a peculiarity pertaining to the swelling of erythrocytes.

2. Tuberculous diseases

The advancement of tuberculous diseases and the erythrocyte sedimentation rate are closely related to each other as proved by numerous scholars, such as: Westergren ${ }^{201}$ and after him Benninghof ${ }^{211}$ and others. ${ }^{22)-}$ 83) These writers have reported that the cause of above fact is due to the increase of globulin and fibrinogen in blood. Ito, Seki and Nakazawa $^{84)}$ have proved that the colloid-osmotic pressure of the blood of phthisical patients is generally within the range of normal values among the light cases and decreases in serious cases. Referring to the reports on this problem and from our own observations it is concluded that some change must have occurred in its colloid-chemical state, that is, the quadity. 
Fig 1

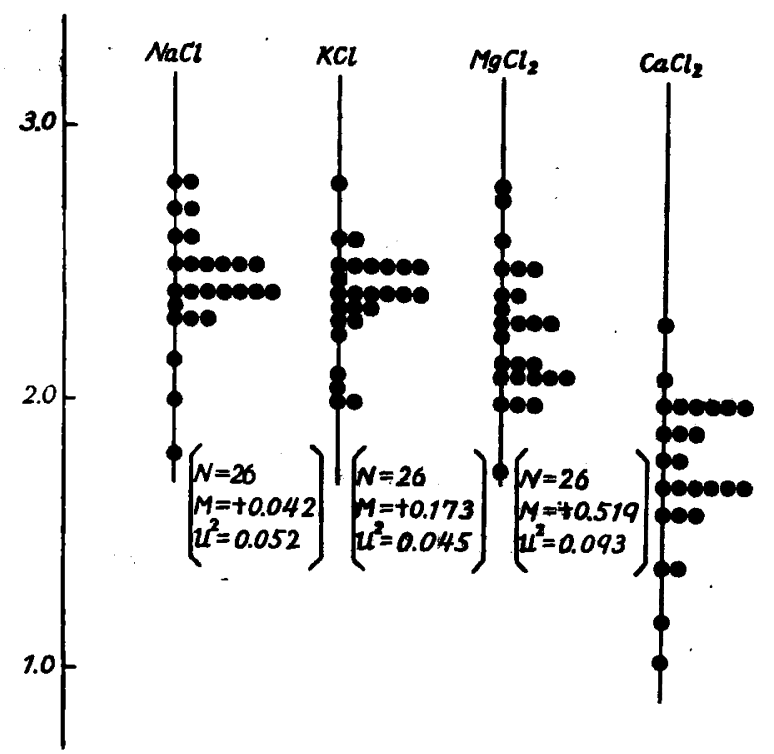

TABLE II

\begin{tabular}{|c|c|c|c|c|c|c|}
\hline Nr. & Age & nder & $\mathrm{NaCl}$ & $\mathbf{K C l}$ & $\mathrm{MgCl}_{2}$ & $\mathrm{CaCl}_{2}$ \\
\hline 1 & 20 , & 今 & 2.1 & 2.4 & 2.25 & 1.9 \\
\hline 2 & 16 , & 옹 & 2.5 . & 2.5 & 2.4 & 2.15 \\
\hline 3 & 26, & ชิ & 2.3 & 2.4 & 2.1 & 1.8 \\
\hline 4 & 28, & ช & 2.4 & 2.4 & 2.35 & 1.8 \\
\hline 5 & 22 , & ช & 2.3 & 2.5 & 2.35 & 2.1 \\
\hline 6 & 24 , & ธิ & 2.35 & 2.5 & 2.3 & 1.7 \\
\hline 7 & 21, & 今 & 2.3 & 2.5 & 2.25 & 2.0 \\
\hline 8 & 59 , & 우 & 2.2 & 2.3 & $\cdot 2.3$ & 1.7 \\
\hline 9 & 26 , & 우 & 2.3 & 2.35 & 2.15 & 1.7 \\
\hline 10 & 20 , & ㅇ & 2.3 & 2.4 & 2.35 & 2.1 \\
\hline 11 & 19 , & 우 & 2.35 & 2.6 & 2.4 & 1.8 \\
\hline 12 & 24, & 우 & 2.55 & 2.6 & 2.4 & 1.8 \\
\hline 13 & 18, & $q$ & 2.4 & 2.5 & 2.55 & 1.8 \\
\hline 14 & 19, & 우 & 2.5 & 2.6 & 2.3 & 1.7 \\
\hline 15 & 32, & 우 & 2.4 & 2.45 & 2.25 & 1.8 \\
\hline 16 & 28, & ㅇ & 2.4 & 2.5 & 2.3 & 1.75 \\
\hline 17 & 91, & q & 2.6 & 2.75 & 2.25 & 1.7 \\
\hline
\end{tabular}

of bloodprotein must have changed in cases of tuberculous diseases. With regard to the quantitative change of mineral matters in blood in cases of tuberculous diseases, Otto ${ }^{86}$ ? and others ${ }^{881}{ }^{-40}$ ) have made numerous re- 
Fig 2.

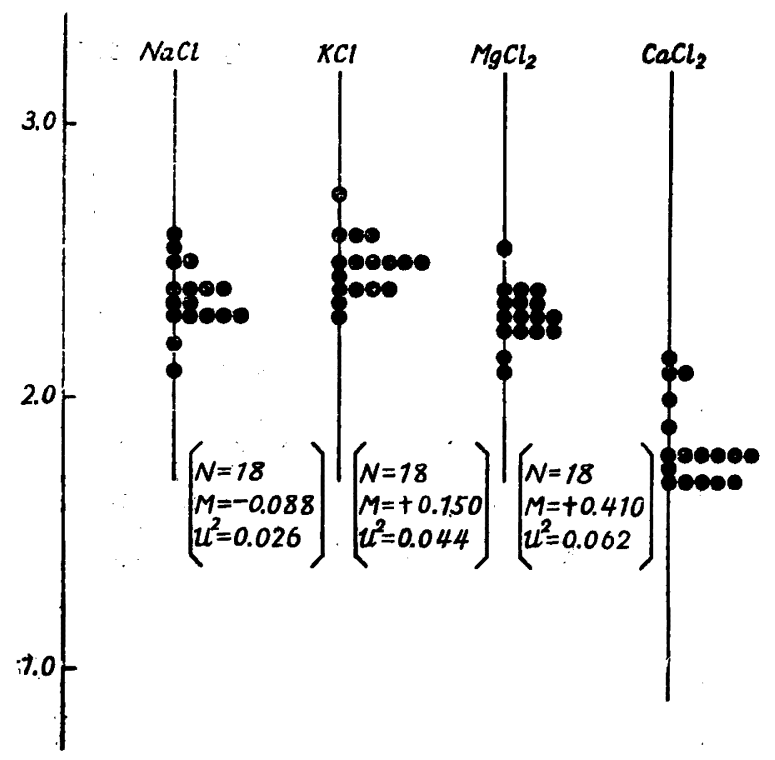

ports during their days. Some variations have been found in their reports, though scarcely no scholar has denoted any special important variations. Close observation of qualitative change of bloodprotein which is closely connected with swelling, discloses that there are some qualitative changes in the erythrocyte colloid, and therefore, I undertook the problem of tuberculous diseases and its relation to the swelling of tubercular patients erythrocytes.

Tubercular patient were divided into 3 groups; i.e. 1) slight cases, 2) serious cases of pulmonary tuberculosis, 3) tuberculous pleurisy, peritonitis and meningitis.

i) Slight cases of pulmonary tuberculosis. Observation on 17 slight cases of pulmonary tuberculosis resulted in data as stated in Tab. II. These patients appeared to have slight symptoms as clearly indicated by clinical diagnosis and X-ray examinations. The patient's swelling results were: Na-swelling 2.3-2.5; K-swelling 2.4-2.6; Mg-swelling 2.2-2.4 and Ca-swelling 1.7-2.0. At a glance, we can not recognize the great difference comparing with healthy persons on the volume and the order of the each swelling. Statistic figures as in Fig. 2, show that a slight difference can be detected. No significant difference exists between Na-swelling and $\mathrm{K}$-swelling as in healthy persons, and there is no significant difference between $\mathrm{K}$-swelling and $\mathrm{Mg}$-swelling, because $\mathrm{M}=+0.150, \mathrm{U}^{2}=0.044$, as found when observing healthy persons. When the value of $\mathrm{Mg}$-swelling 
of slight pulmonary patients was compared with healthy persons statistically, minute significant differences were observed and also the fact that $\mathrm{Mg}$ swelling at the beginning of pulmonary tuberculosis is greater than that of healthy person was demonstrated, and a significant difference between Mg-swelling and Ca-swelling was also noted. In other words, there is little change of Na-swelling, $\mathrm{K}$-swelling and Ca-swelling: only the value of $\mathrm{Mg}$-swelling becomes greater and it can be described that there 3 swellings $(\mathrm{Mg}, \mathrm{Na}$ and $\mathrm{K})$ generally stand on the same level.

$$
\mathrm{Na}=\mathrm{K}=\mathrm{Mg}>\mathrm{Ca} \text {. }
$$

ii) Serious cases of pulmonary tuberculosis. Observations were made on 23 patients possessing marked lung cavities and with No. 4 or more of Gaffky's scale, due to pulmonary tuberculosis on both side, whose body temperatures showed little or no variation due to their being in the hospital. (Tab. III and Fig. 3).

Observation showed that: Na-swelling was 2.1-2.5, K-swelling 2.22.6, Mg-swelling 1.9-2.5 and Ca-swelling 1.7-2.0, as shown in the Table.

TABLE III

\begin{tabular}{|c|c|c|c|c|c|c|}
\hline \multirow{2}{*}{$\frac{\text { Nr. }}{1}$} & \multicolumn{2}{|c|}{ Age and gender } & \multirow{2}{*}{$\frac{\mathrm{NaCl}}{2.4}$} & \multirow{2}{*}{$\frac{\mathrm{KCl}}{2.6}$} & \multirow{2}{*}{$\frac{\mathrm{MgCl}_{2}}{1.9}$} & \multirow{2}{*}{$\frac{\mathrm{CaCl}_{2}}{1.8}$} \\
\hline & 21, & $\hat{\mathbf{o}}$ & & & & \\
\hline 2 & 28, & 今 & 2.4 & 2.3 & 2.1 . & 1.9 \\
\hline 3 & 33, & 今 & 2.1 & 2.2 & 1.95 & 2.0 \\
\hline 4 & 70 & ชิ & 2.35 & 2.5 & 2.3 & 2.1 \\
\hline 5 & 27, & ช & 2.3 & 2.35 & 2.1 & 2.0 \\
\hline 6 & 27, & 今 & 2.2 & 2.4 & 2.1 & 1.9 \\
\hline 7 & 38, & 今 & 2.3 & 2.25 & 2.2 & 1.8 \\
\hline 8 & 19 & $\delta$ & 2.1 & 2.4 & 2.2 & 1.9 \\
\hline 9 & 29 , & ช & 2.25 & 2.4 & 2.45 & 2.0 \\
\hline 10 & 32, & 今 & 2.1 & 2.3 & 2.2 & 1.9 \\
\hline 11 & 27, & 우 & 2.1 & 2.8 & 2.1 & 1.8 \\
\hline 12 & 22 , & ㅇ & 2.1 & 2.25 & 2.1 & 2.1 \\
\hline 13 & 22 , & 우 & 2.3 & 2.4 & 2.4 & 1.9 \\
\hline 14 & 27 , & 우 & 2.2 & 2.3 & 2.2 & 2.0 \\
\hline 15 & 24, & $q$ & 2.5 & 2.4 & 2.3 & 1.7 \\
\hline 16 & 23 & 우 & 2.4 & 2.3 & 2.15 & 1.65 \\
\hline 17 & 32 , & 우 & 2.1 & 2.2 & 2.2 & 1.9 \\
\hline 18 & 50 & 우 & 2.2 & 2.3 & 2.4 & 1.9 \\
\hline 19 & 32, & 우 & 2.1 & 2.2 & 2.3 & 1.8 \\
\hline 20 & 25 , & 우 & 2.55 & 2.6 & 2.4 & 1.8 \\
\hline 21 & 18 , & \& & 2.4 & 2.5 & 2.55 & 1.8 \\
\hline 22 & 18 & 우 & 2.5 & 2.6 & 2.3 & 1.7 \\
\hline 23 & 21 , & 우 & 2.35 & 2.5 & 2.25 & 1.7 \\
\hline
\end{tabular}


Fig. 3.

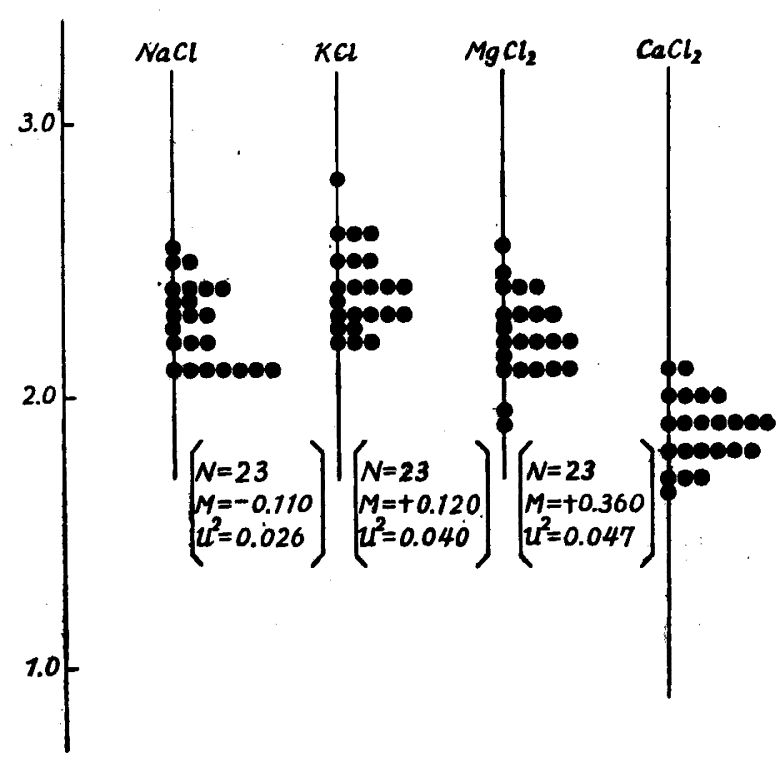

Comparing these results, $\mathrm{M}=-0.110, \mathrm{U}^{2}=0.026$ were obtained between Na-swelling and K-swelling; this fact is quite opposited to cases in healthy persons who show $\mathbf{M}=+0.042$. Next, comparing $\mathrm{K}$-swelling with $\mathrm{Mg}$ swelling, $\mathrm{M}=+0.120, \mathrm{U}^{2}=0.040$ were obtained. In comparison with that of healthy persons $\mathrm{Mg}$-swelling value approximates that of $\mathrm{K}$-swelling. That is, $\mathbf{M g}$-swelling shows a greater comparative value, Ca-swelling is always the least and shows scarcely any change. In other words, Naswelling tends to be lesser, whereas $\mathrm{Mg}$-swelling a little larger in the serious cases of pulmonary tuberculosis.

$$
\mathrm{Na}<\mathrm{K}=\mathrm{Mg}>\mathrm{Ca}
$$

iii) Tuberculous pleurisy, peritonitis and meningitis. Observations were made on 23 cases suffering from tubercular pleurisy, peritonitis and tuberculous meningitis. The results are shown in Tab. IV and Fig. 4. As shown in the table, Na-swelling was 2.1-2.5, K-swelling 2.3-2.6, Mgswelling 1.8-2.4 and Ca-swelling 1.7-2.5. It was observed by comparing these results that $\mathrm{M}=0.100, \mathrm{U}^{2}=0.010$ between $\mathrm{Na}$-swelling and $\mathrm{K}$ swelling. This fact is opposite to the cases of healthy persons from whom $\mathrm{M}=+0.042$ was obtained, and the contraction of Na-swelling as well as in the serious cases of pulmonary tuberculosis was recognized. Comparing $\mathrm{K}$-swelling with $\mathrm{Mg}$-swelling, $\mathrm{M}=+0.170$ and $\mathrm{U}^{2}=0.044$ were obtained; $\mathrm{Mg}$-swelling approximates $\mathrm{K}$-swelling when compared with the cases of healthy persons-this fact shows that $\mathrm{Mg}$-swelling is augmenting. Ca- 
TABLE: IV

\begin{tabular}{|c|c|c|c|c|c|c|}
\hline $\mathbf{N r}$. & Age : & der & $\mathrm{NaCl}$ & $\mathbf{K C l}$ & $\mathrm{MgCl}_{2}$ & $\mathrm{CaCl}_{2}$ \\
\hline 1 & 17 , & 今 & 2.3 & 3.3 & 1.75 & 2.5 \\
\hline 2 & 19 , & જ & 2.1 & 2.2 & 2.3 & 1.55 \\
\hline 3 & 35 , & ช & 2.15 & 2.3 & 2.1 & 1.6 \\
\hline 4 & 22, & 金 & 2.1 & 2.3 & 2.2 & 1.4 \\
\hline 5 & 22 , & 우 & 2.5 & 2.4 & 2.5 & 2.0 \\
\hline 6 & 21, & 우 & 2.1 & 2.3 & 2.4 & 2.5 \\
\hline 7 & 23, & 우 & 2.5 & 2.6 & 1.9 & 2.6 \\
\hline 8 & 26 , & q & 2.55 & 2.6 & 2.4 & 1.8 \\
\hline 9 & 22 , & 우 & 2.6 & 2.8 & 2.55 & 1.8 \\
\hline 10 & 21 , & ㅇ & 2.35 & 2.5 & 2.1 & 2.4 \\
\hline 11 & 21, & 우 & 2.2 & 2.25 & 2.5 & 1.9 \\
\hline 12 & 23, & ? & 2.1 & 2.3 & 2.2 & 1.8 \\
\hline 13 & 29, & \& & 2.1 & 2.3 & 2.0 & 1.4 \\
\hline 14 & 59 , & ㅇ & 2.2 & 2.3 & 2.3 & 1.7 \\
\hline 15 & 18 , & ? & 2.2 & 2.15 & 1.8 & 1.4 \\
\hline 16 & 32, & 우 & 2.4 & 2.6 & 2.4 & 1.7 \\
\hline 17 & 41, & 우 & 2.2 & 2.3 & 1.7 & 1.55 \\
\hline 18 & 23 , & ? & 2.4 & 2.3 & 1.8 & 1.65 \\
\hline 19 & 23 , & 우 & 2.25 & 2.45 & 2.3 & 2.1 \\
\hline 20 & 19. & q & 2.35 & 2.6 & 2.35 & 1.95 \\
\hline 21 & 27 & F & 2.1 & -2.3 & $2: 05$ & 1.8 \\
\hline 22 & 25 , & 우 & 2.55 & 2.6 & 2.4 & I. 8 \\
\hline 23 & 19, & ㅇ & 2.6 & 2.6 & 2.6 & 1.9 \\
\hline
\end{tabular}

swelling is always the least and shows scarcely any changes compared with that of healthy persons. As stated above, the order of the swelling is the same as during the serious cases of pulmonary tuberculosis. It is obvious that the lesser value of Na-swelling, the greater is the increasing of the value of $\mathrm{Mg}$-swelling.

$$
\mathrm{Na}<\mathrm{K}=\mathrm{Mg}>\mathrm{Ca}
$$

The above mentioned measurements were made on such patients who had entered the critical stages of their illness; and therefore, in order to examine the recovery stage, 13 patients were selected for: observation, those who are in the convalescent stage as based on the findings of clinical examination. The results are shown in Tab. V and Fig. 5, which show: Na-swelling 2.1-2.4; $\mathrm{K}$-swelling 2.2-2.4; $\mathrm{Mg}$-swelling 2.0-2.3; and $\mathrm{Ca}$ swelling 1.7-1.9. Comparing these results, $\mathbf{M}=-0.031$, $\mathrm{U}^{2}=0: 007$. were obtained between Narswelling and K-swelling; the significant difference which have existed among the same group of patients at their critical stages disappears, and the value of $\mathrm{Na}$-swelling approximates that of $\mathrm{K}$ - 
Fig. 4.

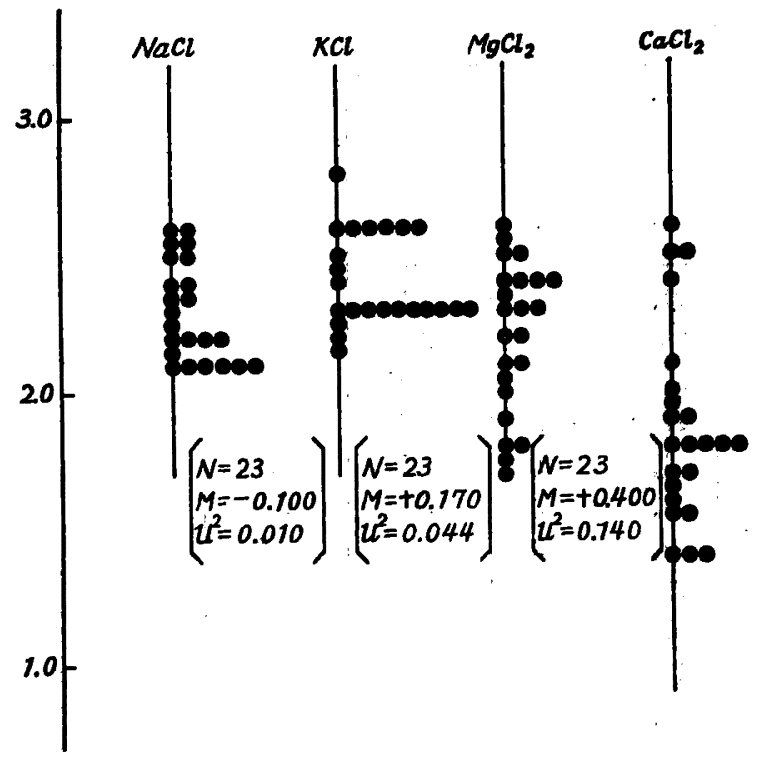

TABLE V

\begin{tabular}{|c|c|c|c|c|c|c|}
\hline Nr. & Age & nder & $\mathrm{NaCl}$ & $\mathrm{KCl}$ & $\mathrm{MgCl}_{2}$ & $\mathrm{CaCl}_{2}$ \\
\hline 1 & 17, & ชิ & 2.35 & 2.3 & 2.2 & 2.1 \\
\hline 2 & 41 , & ธิ & 2.2 & 2.25 & 1.9 & 1.9 \\
\hline 3 & 19, & 今 & 2.1 & 2.1 & 2.0 & 1.7 \\
\hline 4 & 30, & $\delta$ & 2.1 & 2.2 & 2.25 & 1.9 \\
\hline 5 & 28 , & જิ & 2.2 & 2.25 & 2.2 & 1.85 \\
\hline 6 & 37, & 우 & 2.4 & 2.3 & 2.3 & 2.0 \\
\hline 7 & 21 , & 우 & 2.3 & 2.2 & 1.95 & 1.9 \\
\hline 8 & 29, & 우 & 2.2 & 2.25 & 2.2 & 1.8 \\
\hline 9 & 19, & 우 & 2.25 & 2.3 & 2.0 & 1.9 \\
\hline 10 & 18, & 우 & 2.2 & 2.3 & 2.1 & 1.7 \\
\hline 11 & 27 , & 우 & 2.3 & 2.35 & 2.25 & 1.9 \\
\hline 12 & 32 , & 우 & 2.3 & 2.35 & 2.3 & 1.7 \\
\hline 13 & 27 , & \& & 2.5 & 2.45 & 2.3 & 1.7 \\
\hline
\end{tabular}

swelling and the fact that the order of swelling approximates that of healthy persons was established. This fact will also be found when comparative examinations on the Na-swelling of healthy persons is made statistically, Comparing $\mathrm{K}$-swelling with $\mathrm{Mg}$-swelling, $\mathrm{M}=+0.107, \mathrm{U}^{2}=0.019$ which show less significant difference than in healthy persons. Between $\mathrm{Mg}$ swelling and Ca-swelling there is a relationship that $\mathrm{M}=+0.300, \mathrm{U}^{2}=$ 
Jig. 5.

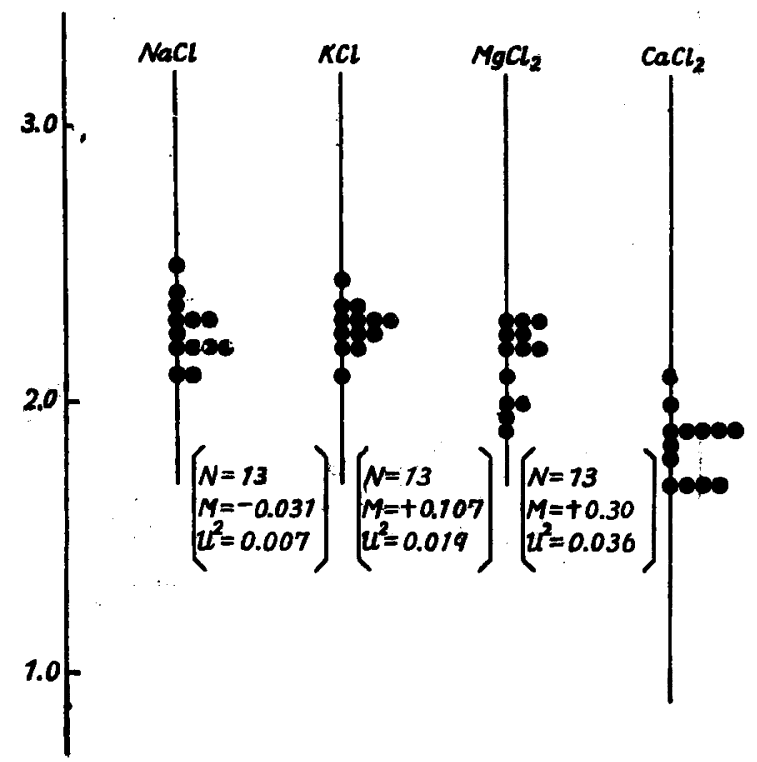

0.036, and significant difference is recognized in this case. Observations confirmed the fact that the order of erythrocytes swelling comes near to that of healthy person. That is: $\mathrm{Na}=\mathrm{K}>\mathrm{Mg}>\mathrm{Ca}$.

3. Cardiovascular diseases

The swelling measurements were made on 13 patients (1I patients with valvular diseases and 2 patients with aortic aneurysm) and the results are shown in Tab. IV and Fig. 6. Na-swelling is 2.2-2.4, $\mathrm{K}$-swelling

TABLE VI

\begin{tabular}{|c|c|c|c|c|c|c|}
\hline Nr. & Age a & ader & $\mathrm{NaCl}$ & KGl & $\mathrm{MgCl}_{2}$ & $\mathrm{CaCl}_{2}$ \\
\hline 1 & 35 , & 今 & 2.25 & 2.3 & 2.35 & 1.85 \\
\hline 2 & 52, & 옹 & 2.4 & 2.5 & 2.3 & 2.0 \\
\hline 3 & 50, & 8 & 2.4 & 2.4 & 2.3 & 1.9 \\
\hline 4 & 51, & $\delta$ & 2.3 & 2.4 & 2.2 & 1.6 \\
\hline 5 & 39, & ช & 2.25 & 2.1 & 2.0 & 1.6 \\
\hline 6 & 22 , & $\delta$ & 2.4 & 2.5 & 2.2 & 2.0 \\
\hline 7 & 19. & s. & 2.2. & 2.05 & 2.1 & 1,8 \\
\hline 8 & 46 , & ธ & 2.2 & 2.4 & 22 & 1.9 \\
\hline 9 & 47 . & 우 & 2.4 & 2.5 & 24 & 1.9 \\
\hline 10 & 40, & 우 & 2.3 & 2.5 & 22 & 1.9 \\
\hline 11 & 57 , & q & 2.4 & 2.45 & 2.2 & 2.0 \\
\hline 12 & 25, & 우 & 2.3 & 2.05 . & 2.0 & 1.75 \\
\hline 13 & 24, & $q$ & 2.3 & 2.0 & 2.05 & 1.8 \\
\hline
\end{tabular}




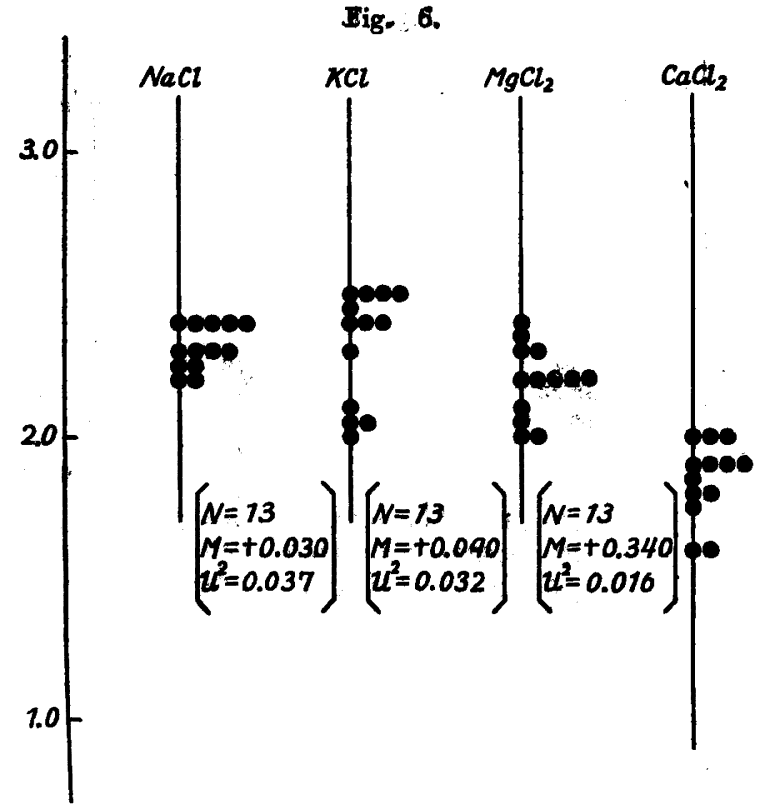

2.1-2.5, Mg-swelling 2.0-2.3 and Ca-swielling 1.6-2.0. By statisticar investigation, it was found that $M=+0.030, U^{2}=0.037$ between $\mathrm{Na}$-swelling and $\mathrm{K}$-swelling and no significant difference existed. Next, $\mathbf{M}=+0.090$, $\mathrm{U}^{2}=0.033$ were obtained between $\mathrm{K}$-swelling and $\mathrm{Mg}$-swelling. $\mathrm{Mg}$ swelling is rather small than $K$-swelling, and $M=+0.34, U^{2}=0.016$ were obtained betweén $\mathrm{Mg}$-swelling and Ca-swelling. These values show that Ga-swelling too is very small. This relationship is similar to the case of healthy persons and the order is:

$$
\mathrm{N}=\mathrm{K}>\mathrm{Mg}>\mathrm{Ca} \text {. }
$$

There is no remarkable change in this cases. In addition, as shown in Table VII and Fig. 7, 6 cases of essential hypertension were examined, but they can not be objects of the accuracy of the statistical examination.

4. Nephritis

It is well known fact that in cases of nephritis there is always some TABLE. VII

\begin{tabular}{|c|c|c|c|c|c|c|}
\hline Nr. & Age & nder & $\mathrm{NaCl}$ & $\mathrm{KCl}$ & $\mathrm{MgCl}_{2}^{-}$ & $\mathrm{CaCl}_{2}$ \\
\hline 1 & 57 , & 今 & 2.4 & 2.5 & 2.65 . & 1.9 \\
\hline 2 & 53, & $\delta$ & 2.3 & 2.4 & 2.2 & 1.8 \\
\hline 3 & 56 , & 今 & 2.4 & $2.6 \%$ & 2.5 & 1.9 \\
\hline 4 & 62 , & \& & 2.2 & 2.4 & 2.4 & 2.0 \\
\hline .5 & 56 , & 우 & 2.45 & 2.6 : & 2.5 & 19 \\
\hline 6 & 46. & 우 & 2.5 & 2.6 & 2.4 & 2.0 \\
\hline
\end{tabular}


Fig.: 7.

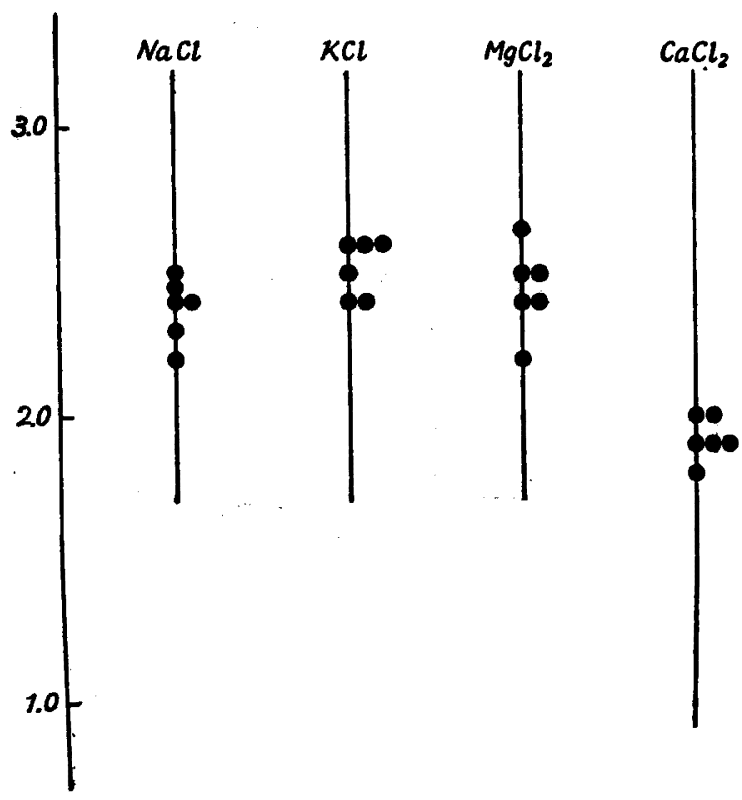

variations of the colloid contained in the human tissue. Therefore, as it can be expected that there is some variation in the protein of erythrocyte, the swelling measurements were made on 9 nephritis patients, and as shown in Tab. VIII and Fig. 8, which show Na-swelling 2.2-2.4, K-swelling 2.3-2.4, Mg-swelling 2.2-2.4 and Ca-swelling 1.9-2.0. As sufficient patients for observation in this particular case were not available and also difficult to express statistically and theoretically, however, as shown in Fig. 8, no remarkable difference existed between Na-swelling and $\mathrm{K}$-swelling, and it is also difficult to recognize the significant difference between

TABLE VIII

\begin{tabular}{c|cc|c|c|c|c}
\hline Nr. & \multicolumn{2}{|c|}{ Age ond gender } & $\mathrm{NaCl}$ & $\mathrm{KCl}$ & $\mathrm{MgCl}_{\mathbf{2}}$ & $\mathrm{C}_{2 \mathrm{Cl}_{2}}$ \\
\hline $\mathrm{I}$ & 44, & $\delta$ & 2.4 & 2.4 & 2.5 & 2.0 \\
2 & 29, & $\delta$ & 2.2 & 2.3 & 2.4 & 1.8 \\
3 & 30, & $\delta$ & 2.4 & 2.4 & 2.6 & 1.6 \\
4 & 40, & $\delta$ & 2.4 & 2.4 & 2.3 & 1.9 \\
5 & 51, & $\delta$ & 2.2 & 2.25 & 2.2 & 1.9 \\
6 & 50, & $\delta$ & 2.4 & 2.35 & 2.4 & 2.0 \\
7 & 55, & $\&$ & 2.4 & 2.5 & 2.2 & 1.9 \\
8 & 19, & $\&$ & 2.4 & 2.3 & 2.15 & 1.85 \\
9 & 32, & $f$ & 2.3 & 2.4 & 2.4 & 1.9
\end{tabular}


Fig. 8.

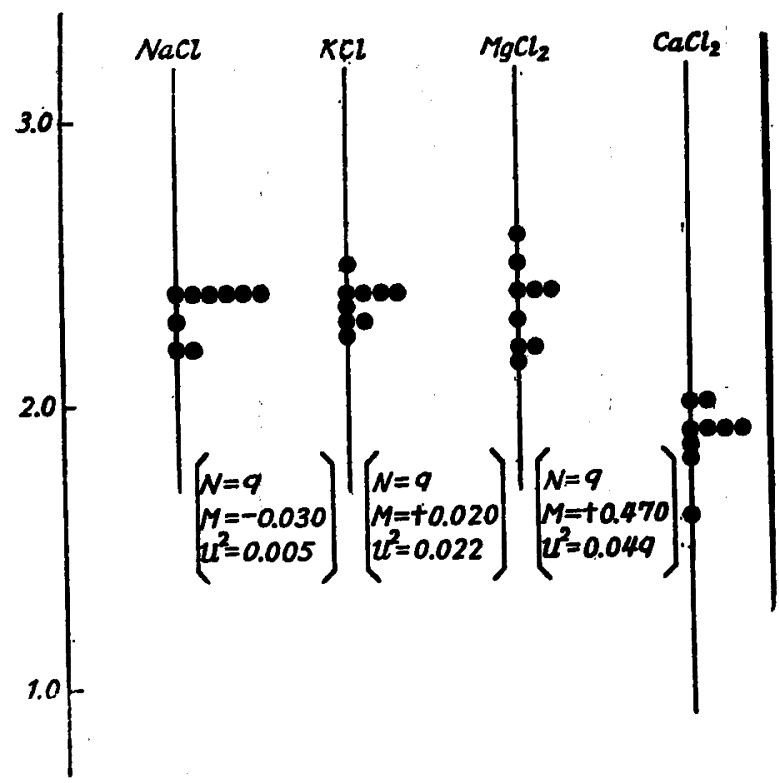

$\mathrm{K}$-swelling and $\mathrm{Mg}$-swelling. But by calculation, the difference between $\mathrm{K}$-swelling and $\mathrm{Mg}$-swelling, $\mathrm{M}=+0.020, \mathrm{U}^{\mathbf{2}}=0.022$ were obtained and both were regarded as being nearly equal. A remarkable difference existed between $\mathrm{Mg}$-swelling and Ca-swelling. Here, Ca-swelling is always the least, and the order of swelling is as follows:

$$
\mathrm{Na}=\mathrm{K}=\mathrm{Mg}>\mathrm{Ca} \text {. }
$$

In nephritis, $\mathrm{Mg}$-swelling increases as compared with that of a healthy person.

\section{Anemia}

Observations were undertaken mainly on 9 patients with simple anemia, and as shown in Tab. IX and Fig. 9 which show: Na-swelling 2.0-2.4, K-swelling 2.0-2.5, Mg-swelling 2.0-2.6 and Ca-swelling 1.72.0. The value of Ca-swelling showed a slight decrease whereas $\mathrm{Mg}$ swelling an increase. In this case, a statistical examination in the strict sense of the term can not be conducted, but, when experimented on patients, calculation was tried on the assumption that it is possible to do so. It was found that $\mathrm{M}=-0.120, \mathrm{U}^{2}=0.124$ between Na-swelling and $\mathrm{K}$-swelling mean a minute contraction of Na-swelling. There is a relation that $\mathrm{M}=-0.06, \mathrm{U}^{2}=0.080$ between $\mathrm{K}$-swelling and $\mathrm{Mg}$-swelling, and any difference is not to be recognized. It is obvious that there is a comparative augment of $\mathrm{Mg}$-swelling in such a case. Here, it is needless to say that Ca-swelling is the least, and therefore the order of swelling is 
TABLE IX

\begin{tabular}{|c|c|c|c|c|c|c|}
\hline Nr. & \multicolumn{2}{|c|}{ Age and gender } & $\mathrm{NaCl}$ & $\mathrm{KCl}$ & $\mathrm{MgCl}_{2}$ & $\mathrm{CaCl}_{2}$ \\
\hline 1 & 48, & ภิ & 2.2 & 2.5 & 2.4 & 1.8 \\
\hline 2 & 58 , & 今 & 2.4 & 2.35 & 2.5 & 1.7 \\
\hline 3 & 20, & 今 & 2.1 & 2.0 & 2.1 & 1.7 \\
\hline 4 & 19, & 今 & 1.9 & 2.65 & 1.5 & 2.0 \\
\hline 5 & 51, & ㅇ & 2.8 & 2.6, & 2.6 & 2.1 \\
\hline 6 & 31, & + & 2.4 & 2.05 & 2.6 & 1.7 \\
\hline 7 & 16 , & $q$ & 2.2 & 2.35 & 2.4 & 2.0 \\
\hline 3 & 16 , & ㅇ & 2.4 & 2.3 & 1.9 & 2.0 \\
\hline 9 & 28, & \& & 2.4 & 2.9 & 2.6 & 2.0 \\
\hline
\end{tabular}

Fig. 9.

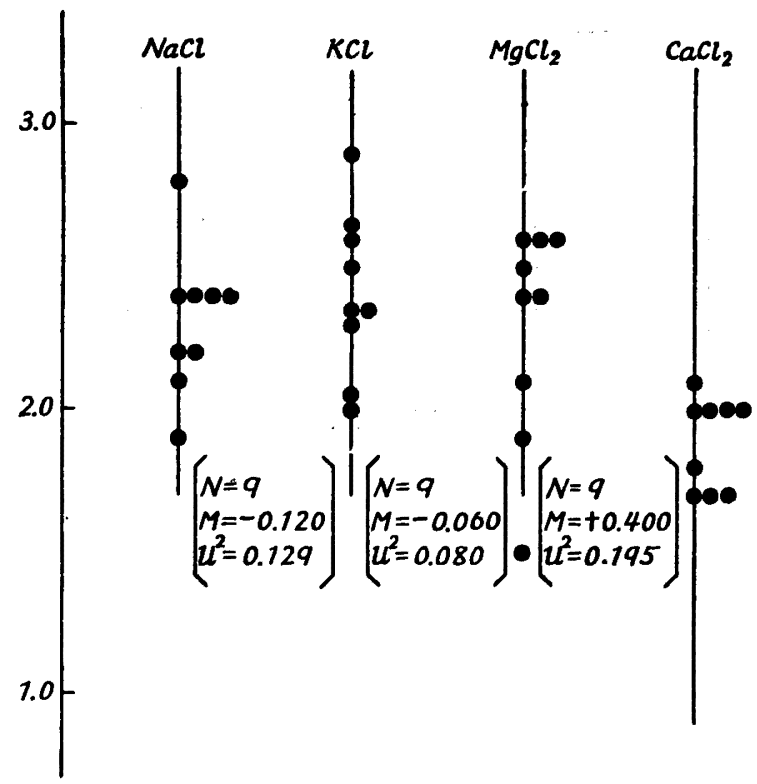

supposed to be as follows:

$$
\mathrm{Na}<\mathrm{K}=\mathrm{Mg}>\mathrm{Ca} .
$$

The comparative augment of $\mathrm{Mg}$-swelling and contraction of $\mathrm{Na}$ swelling will be recognized in a case of noticeable anemia.

6. Gastric cancer

Observations were made on 19 patients with gastric cancer as shown in Tab. X and Fig. 10, and Na-swelling was 2.3-2.5, K-swelling 2.3-2.5, Mg-swelling 2.2-2.5 and Ca-swelling was 1.6-2.0; it seems that $\mathrm{Mg}$ swelling augments comparatively. There is the relation which is: $\mathbf{M}=$ 
Table $\mathbf{X}$

\begin{tabular}{c|cc|c|c|c|c}
\hline Nr. & \multicolumn{2}{|c|}{ Age and gender } & $\mathrm{NaCl}$ & $\mathrm{KG}$ & $\mathrm{MgCl}_{2}$ & $\mathrm{CaCl}_{2}$ \\
\hline 1 & 52, & $\delta$ & 2.5 & 2.4 & 2.5 & 1.6 \\
2 & 49, & $\delta$ & 2.7 & 2.5 & 2.1 & 1.8 \\
3 & 56, & $\delta$ & 2.65 & 2.3 & 2.2 & 1.9 \\
4 & 36, & $\delta$ & 2.3 & 2.4 & 2.15 & 1.95 \\
5 & 56, & $\delta$ & 2.3 & 2.5 & 2.3 & 2.0 \\
6 & 53, & $\delta$ & 2.4 & 2.45 & 2.25 & 1.7 \\
7 & 62, & $\delta$ & 2.5 & 2.55 & 1.95 & 2.3 \\
8 & 25, & $\delta$ & 2.3 & 2.25 & 2.2 & 1.8 \\
9 & 62, & $\delta$ & 2.4 & 2.6 & 2.5 & 2.0 \\
10 & 29, & $\delta$ & 2.3 & 2.35 & 2.4 & 1.9 \\
11 & 55, & $\delta$ & 2.3 & 2.3 & 2.5 & 2.1 \\
12 & 66, & $\delta$ & 2.6 & 2.5 & 2.4 & 1.9 \\
13 & 63, & $\delta$ & 2.5 & 2.3 & 2.4 & 2.0 \\
14 & 38, & $\delta$ & 2.45 & 2.4 & 2.35 & 1.9 \\
15 & 62, & $\delta$ & 2.3 & 2.5 & 2.4 & 2.0 \\
16 & 49, & $\delta$ & 2.5 & 2.5 & 2.4 & 1.6 \\
17 & 46, & $\&$ & 2.7 & 2.6 & 2.2 & 1.8 \\
18 & 66, & $\&$ & 2.1 & 2.4 & 2.2 & 2.0 \\
19 & 49, & $\&$ & 2.4 & 2.2 & 2.3 & 2.0
\end{tabular}

Fig. 10.

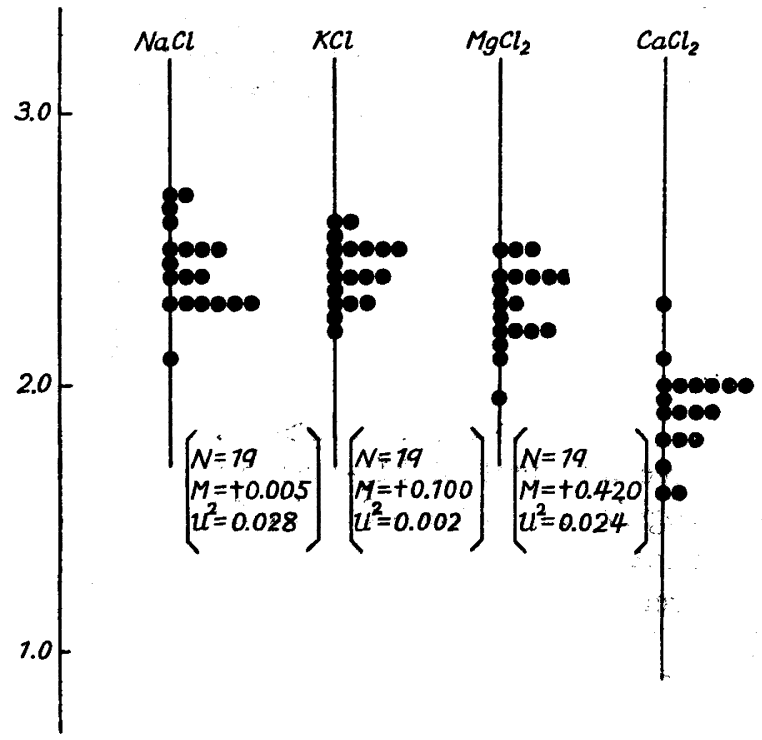


$+0.005, \mathrm{U}^{2}=0.028$ between Na-swelling and $\mathrm{K}$-swelling. Here, of course, no significant difference exists, but $U^{2}$ and $M$ are small, compared. with a healthy person. This fact proves that the value of Na-swelling is nearly equal to that of $\mathbf{K}$-swelling, i.e. a slight decrease of Na-swelling. Next, K-swelling was compared with $\mathbf{M g}$-swelling, and so the results were $\mathrm{M}=+0.100, \mathrm{U}^{2}=0.002$. And there was no significant difference between $\mathrm{K}$-swelling and $\mathrm{Mg}$-swelling; and therefore comparative augument of Mg-swelling was proved. There was a very remarkable difference between $\mathrm{Mg}$-swelling and Ca-swelling, the latter was the least. Therefore the order of swelling can be stated as:

$$
\mathrm{Na} \fallingdotseq \mathrm{K}=\mathrm{Mg}>\mathrm{Ca} \text {. }
$$

It was considered that there is a comparative augment of $\mathrm{Mg}$-swelling and that comparative contraction of Na-swelling was probable in the cases of gastric cancer.

7. Bronchial asthma

Bronchial asthma is closely connected with autonomic nerves and blood colloid is influenced by the same nerve too. Now, observations were undertaken on 11 patients of bronchial asthma (Tab. XI and Fig. 11). It was found that Na-swelling was 2.2-2.6, $\mathrm{K}$-swelling 2.3-2.7, Mg-swelling 2.3-2.6 and Ca-swelling 1.6-2.0. It is probable that no marked difference exists among $\mathrm{Na}-, \mathrm{K}$ - and $\mathrm{Mg}$-swellings, but statistically $\mathrm{M}=-0.081$, $\mathrm{U}^{2}=0.020$ were obtained between Na-swelling and $\mathrm{K}$-swelling, therefore a slight difference can be recognized by mathematical calculations. Between K-swelling and $\mathrm{Mg}$-swelling no significant difference can be observed because of $M=+0.150$ and $U^{2}=0.018$. Taking consideration of decrease of $\mathrm{Mg}$-swelling with the significant difference in the case of healthy persons, comparative augment of $\mathbf{M g}$-swelling was demonstrated in this case.

TABLE XI

\begin{tabular}{|c|c|c|c|c|c|c|}
\hline $\mathrm{N}_{\mathrm{r}}$ & Age & ader & $\mathrm{NaCl}$ & $\mathbf{K C l}$ & $\mathrm{MgCl}_{2}$ & $\mathrm{CaCl}_{2}$ \\
\hline 1 & 21, & ठิ & 2.4 & 2.5 & 2.3 & 1.9 \\
\hline 2 & 24, & 8 & 2.5 & 2.55 & 2.45 & 2.0 \\
\hline 3 & 31 , & 옹 & 2.6 & 2.7 & 2.6 & 1.8 \\
\hline 4 & 20, & ธ & 2.2 & 2.5 & 2.3 & 1.8 \\
\hline 5 & 25, & ช & 2.2 & 2.3 & 2.15 & 1.6 \\
\hline 6 & 31, & f & 2.45 & 2.7 & 2.4 & 2.0 \\
\hline 7 & 26 ; & 우 & 2.4 & 2.25 & 2.1 & 1.4 \\
\hline 8 & 23 , & क & 2.35 & 2.2 & 2.15 & 1.6 \\
\hline 9 & 20; & 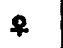 & 2.7 & 2.6 & 2.6 & $\quad 2.0$ \\
\hline 10 & 59 , & 우 & 2.3 & 2.5 & 2.3 & 1.55 \\
\hline 11 & 19; & \& & 2.4 & 2.6 & 2.3 & 2.0 \\
\hline
\end{tabular}


Fig. 11.

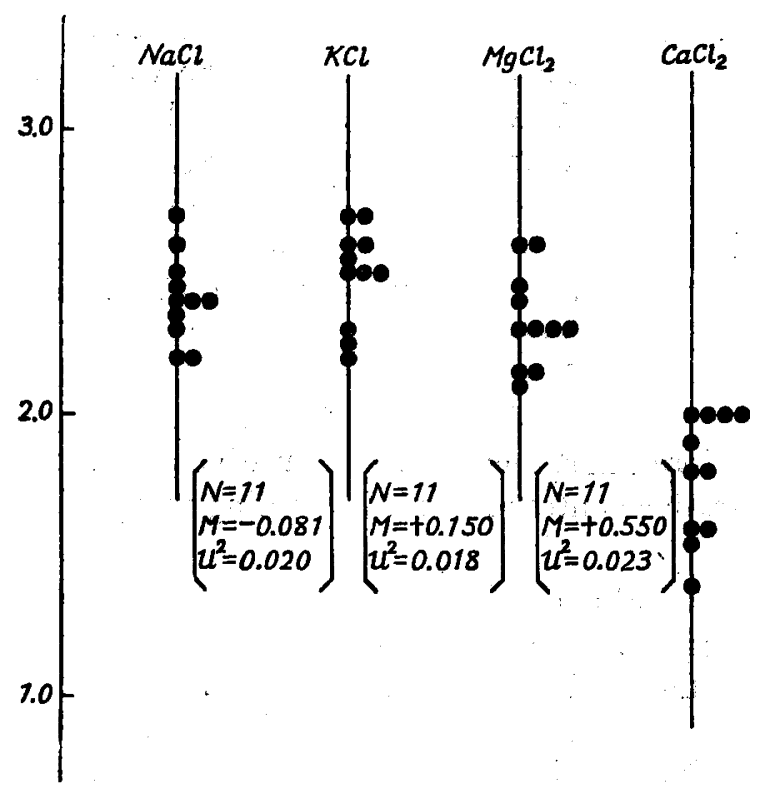

Ca-swelling is the least, therefore the order of swelling can be stated as:

$$
\mathrm{Na} \fallingdotseq \mathrm{K}=\mathbf{M g}>\mathrm{Ca} \text {. }
$$

It is supposed that there is an augment of $\mathrm{Mg}$-swelling and a little comparative decrease of Nà-swelling in bronchial asthma.

8. Beriberi

Observations were made on 13 patients with beriberi as shown in TABLE XII

\begin{tabular}{|c|c|c|c|c|c|c|}
\hline $\mathrm{Nr}$. & Age & nder & $\mathrm{NaCl}$ & $\mathrm{KCl}$ & $\mathrm{MgCl}_{2}$ & $\mathrm{CaCl}_{2}$ \\
\hline 1 & 22 , & $\widehat{\delta}$ & 2.3 & 2.4 & 2.0 & 1.8 \\
\hline 2 & 14, & ชิ & 2.6 & 2.55 & 2.3 & 1.8 \\
\hline 3 & 22 , & \& & 2.6 & 2.4 & 2.5 & 1.9 \\
\hline 4 & 28, & ㅇ & 2.05 & 2.1 & 2.1 & 1.9 \\
\hline 5 & 18 , & + & 2.2 & 2.25 & 2.1 & 2.0 \\
\hline 6 & 24, & $q$ & 2.5 & 2.55 & 2.3 & 1.9 \\
\hline 7 & 22 , & ㅇ & 2.45 & 2.4 & 2.35 & 2.0 \\
\hline 8 & 29 , & 우 & 2.1 & 2.15 & 2.2 & 1.9 \\
\hline 9 & 26, & ? & 2.6 & 2.5 & 2.0 & 1.9 \\
\hline 10 & 41, & 8 & 2.3 & 2.25 & 2.3 & 2.0 \\
\hline 11 & 23; & ㅇ & 2.2 & 2.25 & 2.1 & 1.9 \\
\hline 12 & 22, & 웅 & 2.5 & 2.3 & 2.3 & 2.0 \\
\hline 13 & 21 , & ? & 2.35 & 2.4 & 2.2 & 1.8 \\
\hline
\end{tabular}


Fig. 12.

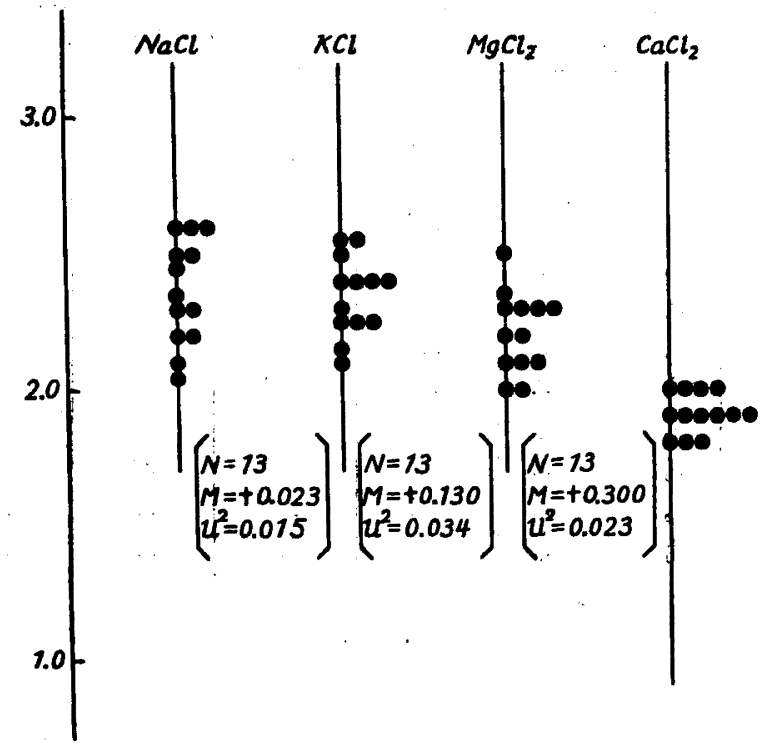

Tab. XII and Fig. 12. As generally accepted, the present-day beriberipatients showed only slight cardiovascular and sensory disturbance with or without traces of edema. The results of this experiments is as follows: $\mathrm{Na}$-swelling is 2.2-2.6, $\mathrm{K}$-swelling 2.2-2.5, $\mathrm{Mg}$-swelling 2.1-2.3 and $\mathrm{Ca}$ swelling 1.8-2.0, and the order is the same as of healthy persons. Examination by calculation disclosed that $\mathrm{M}=+0.023, \mathrm{U}^{2}=0.015$ between Na-swelling and $\mathbf{K}$-swelling. There is not so much significant difference as in the case of healthy persons, and where $\mathrm{M}=+0.130, \mathrm{U}^{2}=0.034$ were obtained between $\mathrm{K}$-swelling and $\mathrm{Mg}$-swelling. The value approximates that of healthy persons. Between $\mathrm{Mg}$-swelling and Ca-swelling $\mathbf{M}=$ $+0.030, \mathrm{U}^{2}=0.023$ were obtained which showed a remarkable difference. Therefore, at least, in the cases of beriberi as observed the variation on the order of swelling can not be recognized and therefore:

$$
\mathrm{Na}=\mathbf{K}>\mathbf{M g}>\mathbf{C a} \text {. }
$$

9. Croupous pneumonia and typhoid fever

Observations were made on 12 patients with acute croupous pneumonia and 9 patients with typhoid fever (Tab. XIII and Fig. 13, Tab.XIV and Fig. 14).

Firstly, pneumonia patients were observed and Na-swelling was 2.22.5, $\mathrm{K}$-swelling 2.1-2.5, Mg-swelling 2.2-2.5 and Ca-swelling as 1.5-1.9. By comparing these results between $\mathrm{Na}$-swelling and $\mathrm{K}$-swelling, $\mathrm{M}=$ $-0.016, \mathrm{U}^{2}=0.023$ were obtained and there was no significant difference, 
TABLE XIII

\begin{tabular}{|c|c|c|c|c|c|c|}
\hline Nr. & Age & ader & $\mathrm{NaCl}$ & $\mathrm{KCl}$ & $\mathrm{MgCl}_{2}$ & $\mathrm{CaCl}_{2}$ \\
\hline 1 & 20, & 今 & 2.2 & 2.1 & 2.2 & 1.5 \\
\hline 2 & 41, & o & 2.15 & 2.05 & 2.15 & 1.3 \\
\hline 3 & 21, & ઠ & 2.3 & 2.25 & 2.5 & 1.8 \\
\hline 4 & 23 , & ธิ & 2.3 & 2.4 & 2.2 & 1.6 \\
\hline 5 & 10 & ชิ & 2.8 & 2.6 & 3.2 & 2.1 \\
\hline 6 & 49 , & ช & 2.3 & 2.35 & 2.2 & 1.9 \\
\hline 7 & 37 , & જ & 2.3 & 2.4 & 2.2 & 1.7 \\
\hline 8 & 56 , & ㅇ & 2.4 & 2.8 & 2.3 & 2.0 \\
\hline 9 & 37, & ? & 2.5 & 2.4 & 2.6 & 1.9 \\
\hline 10 & 38 , & ? & 2.1 & 2.0 & 2.0 & 1.4 \\
\hline 11 & 41, & ㅇ & 2.4 & 2.3 & 2.2 & 1.5 \\
\hline 12 & 37, & f & 2.5 & 2.5 & 2.9 & 1.9 \\
\hline
\end{tabular}

Fig. 13.

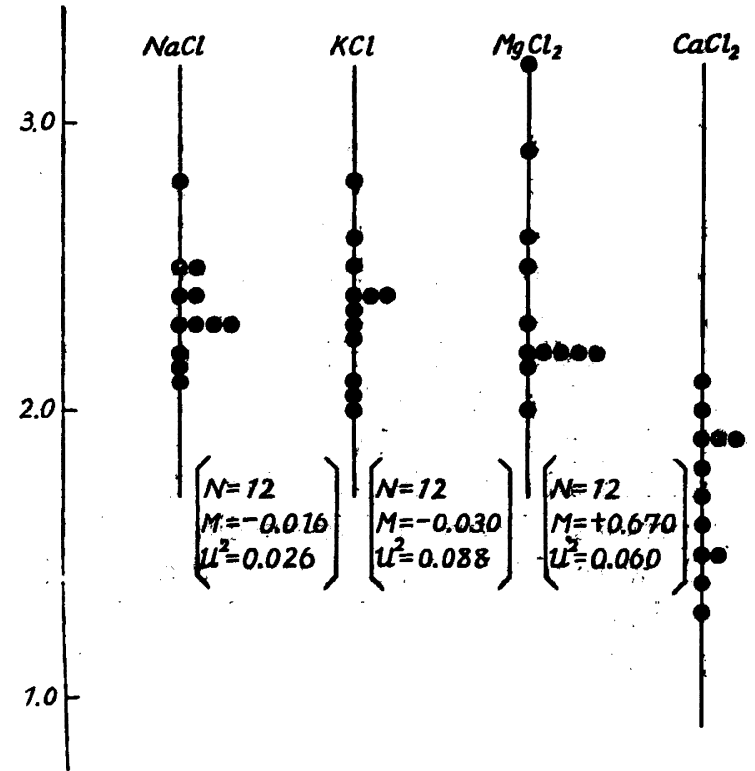

but, in effect it is a probable case that there is a comparative decrease of $\mathrm{Na}$-swelling compared with healthy person. Between K-swelling and Mg-swelling, $M=-0.03, U^{2}=0.088$, which showed no significant statistical difference. Comparative augment of $\mathrm{Mg}$-swelling was found the same as healthy persons. . There is a remarkable difference between $\mathrm{Mg}$-swelling and Ca-swelling statistically, which is rather greater than in the case of 
healthy person, and expressed as:

$\mathrm{Na} \fallingdotseq \overline{\mathrm{K}}=\mathrm{Mg}>\mathrm{Ca}$.

By this order, the comparative augment of $\mathrm{Mg}$-swelling and that of $\mathrm{Na-swelling} \mathrm{also} \mathrm{was} \mathrm{clearly} \mathrm{recognized} \mathrm{as} \mathrm{decreasing} \mathrm{comparatively.}$

TABLE XIV

\begin{tabular}{|c|c|c|c|c|c|}
\hline Nr. & Age and gender & $\mathrm{NaCl}$ & $\mathbf{K C l}$ & $\mathrm{CaCl}_{2}$ & $\mathrm{MgCl}_{2}$ \\
\hline 1 & . & 2.1 & 2.1 & 1.9 & 1.55 \\
\hline 2 & o & 2.1 & 2.2 & 1.9 & 1.6 \\
\hline 3 & 43 & 2.1 & 2.4 & 2.3 & 1.5 \\
\hline 4 & 44 & 2.1 & 2.3 & 2.0 & 1.95 \\
\hline 5 & 22, & 2.0 & 2.3 & 1.9 & 1.9 \\
\hline 6 & 37, & $\therefore 1.9$ & 2.1 & 1.9 & 1.4 \\
\hline 7 & 23, & 2.0 & 2.25 & 1.9 & 1.5 \\
\hline 8 & 17 & 2.15 & 2.4 & 2.05 & 1.9 \\
\hline 9 & 41, & 2.1 & 2.3 & 2.0 & 1.9 \\
\hline
\end{tabular}

Fig. 14.

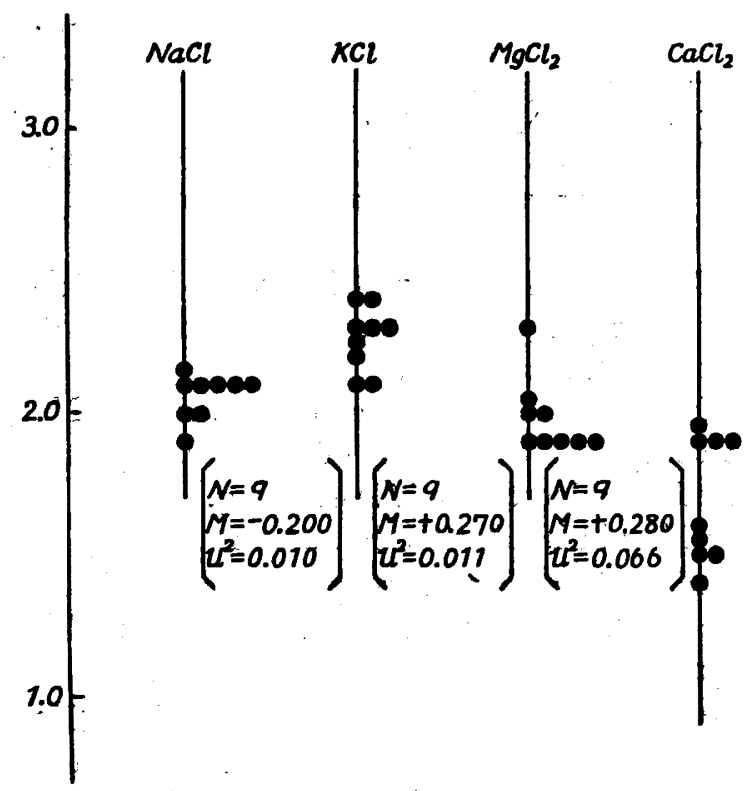

Typhoid fever patients showed the order of swelling as per Tab. XIV as also as follows: $\mathrm{Na}<\mathrm{K}>\mathrm{Mg}>\mathrm{Ca}$. Which shows that the decrease of Na-swelling is a considered fact. 


\section{SUMMARY}

By summarizing the facts and data obtained from the fore-mentioned experiments:

1. The order of erythrocytes swelling in healthy person is

$$
\mathrm{Na}=\mathrm{K}>\mathrm{Mg}>\mathrm{Ca}
$$

and being different from Hofmeister's order, and is proper only to erythrocyte.

2. On tuberculous disease, it has been demonstrated that there is a comparative augment of $\mathrm{Mg}$-swelling in the beginning of pulmonary tuberculosis, and a comparative contraction of $\mathrm{Na}$-swelling and comparative augment of $\mathrm{Mg}$-swelling in the serious cases of pulmonary tuberculosis. By these facts, if Na-swelling turns to normal, it may be considered that it indicates an improvement of the malady.

3. In tuberculous pleurisy, peritonitis and meningitis, the comparative contraction of Na-swelling and the comparative augment of $\mathrm{Mg}$ swelling was recognized in the critical stage of the illness, but in the patients of tuberculous pleurisy and peritonitis who are on their way to recovery, this relationship turns to normal.

4. The order of swelling in cardiovascular disease is recognized as $\mathrm{Na}=\mathrm{K}>\mathrm{Mg}>\mathrm{Ca}$, which is the same as with healthy persons.

5. The order of swelling in nephritis is $\mathrm{Na}=\mathrm{K}=\mathrm{Mg}>\mathrm{Ca}$, or a comparative augment of $\mathbf{M g}$-swelling.

6. The order of swelling in anemia is $\mathrm{Na}<\mathrm{K}=\mathrm{Mg}>\mathrm{Ca}$, or a comparative augment of $\mathrm{Mg}$-swelling and a possible minute contraction of $\mathrm{Na}$ swelling.

7. The order of swelling in gastric cancer is $\mathrm{Na} \fallingdotseq \mathrm{K}=\mathrm{Mg}>\mathrm{Ca}$, or a comparative augment of $\mathrm{Mg}$-swelling, or it appears that there is a comparative contraction of Na-swelling.

8. The order of swelling in bronchial asthma is $\mathrm{Na}=\mathrm{K}=\mathrm{Mg}>\mathrm{Ca}$. There is also a comparative augment of $\mathrm{Mg}$-swelling and, as a matter of fact, there is a minute decrease of Na-swelling.

9. The swelling in beriberi is the same in healthy persons.

10. The order of swelling in croupous pneumonia is $\mathrm{Na} \fallingdotseq \mathrm{K}=\mathrm{Mg}>$ $\mathrm{Ca}$. Besides there is a comparative augment of $\mathrm{Mg}$-swelling, and possibly there is a comparative contraction of Na-swelling.

11. The order of swelling in typhoid fever is $\mathrm{Na}<\mathrm{K}>\mathrm{Mg}>\mathrm{Ca}$, and possibly there is a comparative contraction of Na-swelling.

To sum up the facts on the above mentioned data in a few words as possible, the swelling of erythrocytes in the case of $\mathrm{Na}, \mathrm{K}, \mathrm{Mg}$ and $\mathrm{Ca}-$ 4 kinds of cation, have a peculiarity, i.e., having a different appearance against the swelling of tissue of liver or others. In the case of disease, the 
order of swelling is varied, but the variations in the cases of $\mathrm{K}$-swelling and Ca-swelling are very small: it is $\mathrm{Mg}$-swelling that causes the main variation, and is Na-swelling is a secondary swelling to a $\mathrm{Mg}$-swelling.

Part of the expence of this investigation has been met by grants from the Foundation for Promotion of Scientific. Research of the Education Department.

\section{F. Nakazawa.}

\section{References}

1) Loeb, Arch. ges. Physical., 1838, 61, 1.

2) Hofmeister, ibid., 1891, 28, 210.

3) Overton, ibid., 1902, 92, 346.

4) Ostwald, ibid., 1905, 108, 563.

5) Fischer, Pflüger's Arch., 1908, 124, 69.

6) Ellinger and Heymann, Arch. exper. Pathol., 1921, 93, 336.

7) Hōber, Physicalische Chemie dè Zelle u. Gewebe, Leipzig 1924.

8) Sato, Tohoku J. Exp. Med., 1931, 18, 395.

9) Oyama and Sone, Tohoku Igakuzasshi, 1947, 36, 1.

10) Shimizu and Takahagi, Tohoku Igakuzasshi, 1949, 42, 6.

11) Koeppe, Pflüger's Arch., 1910, 134, 311.

12) Falter and Quittner, Biochem. Z., 1919, 100, 148.

13) Kramer and Tisdall, J. biol. Chem., 1922, 53, 241.

14) György, Biochem. Z., 1924, 281, 152.

15) Hasting, J. Biol. Chem., 1925, 12, 63.

16) Geiger, Arch. Sci. Biol. (It), 1927, 9, 447.

17) Schwarz, Biochem. Z., 1911, 37, 34.

18) Spiro and Ostwald, ibid., 1911, 37, 34.

19) Nakazawa, Nitinaikaishi, 1943, 31, 311.

20) Westergren, Beitr. klin. Tbk., 1921, 46, 285.

21) Benninghof, Münch. med. Wschr., 1921, 1913.

22) Murakami, Chosen-Ikaishi., 1921, 35, 323.

23) Katz, Z. Tbk., 1922, 35, 401.

24) Dreyfus and Hecht, Münch. med. Wschr., 1922, 755.

25) Grafe, Klin. Wschr., 1922, 937.

26) Poindecker and Siess, Wien. klin. Wschr., 1922, 971.

27) Petschacher, Z. f. d. ges. exper. Med., 1923, 36, 22.

28) Krimpfhoff, Beitr. klin. Tbk., 1923, 55, 365.

29) Schmidt, ibid., 1923, 55, 378.

30) Alterthum, ibid., 1923, 55, 511.

31) Schindera, Dtsch. Arch. klin. Med., 1924,.114, 113.

32) Brieger, Schweiz. med. Wschr., 1925, 763.

33) Greischeimer and Johanson, Amer. Jour. Physiol., 1928, 85, 376.

34) Ito, Seki and Nakazawa, Tohoku J. Exp. Med., 1929, 2 \& 3, 254.

35) Otto, D. m. W., 1903, 1, 41.

36) Mayer, D. A. klin. Med., 1907, 90, 408.

37) Vorhoefe, ibid., 1913, 110, 231.

38) Heinelt, Beitr. klin. Tbc., 1926, 62, 799.

39) Marz, Amer. Rev. Tbc., 1925, 1, 250.

40) Hoyle, J. Pharm., 1928, 34, 259. 